\section{Phytochemical study and evaluation of the antimicrobial activity and cytotoxicity of Cuscuta racemosa}

\author{
Helena O. Ferraz, ${ }^{* 1}$ Magali G. Silva, ${ }^{1}$ Rui Carvalho, ${ }^{2}$ Ivana \\ B. Suffredini, ${ }^{3}$ Edna T. M. Kato, ${ }^{4}$ Fernanda Arakaki, ${ }^{4}$ Elfriede \\ M.Bacchi ${ }^{4}$
}

${ }^{1}$ Universidade de Sorocaba, Brazil,

${ }^{2}$ Departmento de Bioquímica, Faculdade de Ciências e Tecnologia da Universidade de Coimbra, Portugal,

${ }^{3}$ Laboratorio de Extração, Universidade Paulista, Brazil,

${ }^{4}$ Departmento de Farmácia, Faculdade de Ciências Farmacêuticas, Universidade de São Paulo, Brazil.
Revista Brasileira de Farmacognosia Brazilian Journal of Pharmacognosy 21(1): 41-46, Jan./Feb. 2011
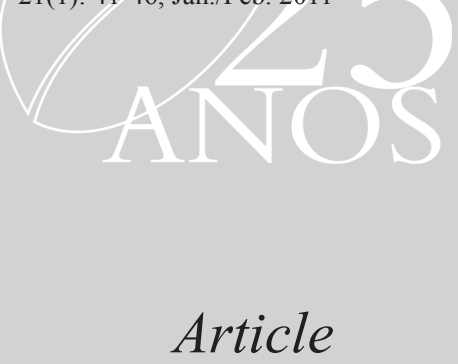

Received 27 Sep 2009

Accepted 13 Jul 2010 Available online 24 Jan 2011

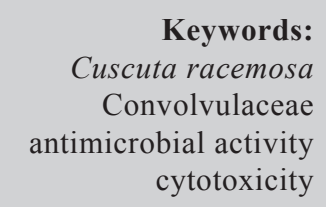

ISSN 0102-695X doi: 10.1590/S0102-695X2011005000005

\section{Introduction}

Parasitic plants are part of a group of taxonomically diverse organisms that include Angiospermae and Gymnospermae. Approximately 4000 species of the division Angiospermae, distributed among 270 genera and 22 families, have parasitic properties. Such plants can be classified as (i) hemiparasites, which contain chlorophyll; and holoparasites, in which chlorophyll is absent; (ii) obligatory parasites, which need to link to an adequate host immediately after germination; and facultative parasites, which are those that associate themselves to other plants after maturity; and (iii) shoot or root parasites, which attach themselves to a host according to the position their haustoria (modified roots) (Press \& Phoenix, 2005; Shen et al., 2006).

The plant species Cuscuta racemosa Mart., a member of the Convolvulaceae family, is a shoot holoparasite, and all the members of the genus are heterothrophic plants that present many morphological and physiological simplifications, such as an absence of cotyledons or radicles in their embryos, scale leaves without vascular tissue and haustoria, all of which represent an adaptation to parasitism (Shen et al., 2006).
These plants present a significant reduction in the genes associated with the photosynthetic mechanism for evolutionary alteration linked to the chloroplast genome (Bungard, 2004) and, therefore, do not exhibit the color green, which has led to the popular names "cipó-chumbo" ("lead-vine") and "fios-de-ovos" ("golden-threads") given to species of C. racemosa Mart. (Correa, 1984).

In Brazil, C. racemosa is usually associated with parasitism in ornamental plants and its occurrence in agricultural crops is unusual (Lorenzi, 2000). This species, originally from Chile, is common over the southeast and southern regions of the country, from the states of Minas Gerais to Rio Grande do Sul. They are perennial, non-chlorophyll, herbaceous, hairless plants, with filiform and delicate stems, exclusively propagated through seeds (Correa, 1984; Lorenzi, 2000).

This plant is used in popular medicine as an anti-inflammatory and a diuretic remedy, for stomach and hepatic disorders, and for treating fresh wounds (Correa, 1984; Lorenzi, 2000). Phytochemical screening for the acute or chronic antiulcer properties of a freezedried sample of the drug and the ethanolic fraction were executed by Alves et al. (1995), with positive results; however, no further studies have been found in existing literature and the purpose of this study is 
thus to contribute to greater knowledge on the subject, with a phytochemical characterization and evaluation of its antimicrobial activity and cytotoxicity in brine shrimp.

\section{Material and Methods}

\section{Plant material}

A sample of the Cuscuta racemosa Mart., Convolvulaceae, complete with flowers, was collected in June, in the Vila Mariana district of the city of São Paulo, where it was parasitizing Hibiscus rosa sinensis L. (registration number SP-351845). The exsicates were deposited in the herbarium of the Botany Institute of São Paulo, under the registration number SP-351844.

\section{Drug preparation, freeze-drying of the crude extract} and fractions

The plant material was selected and was dried in an air-ventilated laboratory oven at $40^{\circ} \mathrm{C}$ for $72 \mathrm{~h}$. The dried plant was ground and extracted through percolation with ethanol $70 \%(\mathrm{v} / \mathrm{v})$. The solution was concentrated at $45{ }^{\circ} \mathrm{C}$ under low pressure and freeze-dried. The yield of this lyophilized crude extract (CE) was $43.96 \%$ of the dried plant material. Part of the lyophilized material was used in the preparation of fractions, in accordance with the sequence of polarity of the solvent employed: $10 \mathrm{~g}$ of the CE was partition-fractionated with 100 $\mathrm{mL}$ of chloroform, shaken for $30 \mathrm{~min}$ and filtered to obtain a liquid fraction (CF). The same procedure was repeated with the residue using an equivalent volume of ethyl acetate (EAF), ethanol (EF) and ethanol/water 1:1 (WEF), which were then evaporated at low pressure and the residues obtained (yields of $0.76 \%, 3.40 \%$, $35.48 \%$ and $60.72 \%$, respectively) were stored under refrigeration (Suffredini et al., 1999).

\section{Phytochemical characterization}

\section{Thin-layer chromatography (TLC)}

A $5.0 \mu \mathrm{L}$ volume of $1.0 \%(\mathrm{~m} / \mathrm{v}) \mathrm{CE}$ and fractions, in addition to standard flavonoids quercetin, rutin and kaempferol $\left(\mathrm{Merck}^{\circledR}\right)$, at a concentration of $0.1 \%$ in methanol, was applied to $0.2 \mathrm{~mm}$ thick silica gel plates $\left(\right.$ Merck $\left.^{\circledR}\right)$. The following TLC system was used: ethyl acetate:methyl ethyl ketone:formic acid:water $(57: 27: 5: 10, \mathrm{v} / \mathrm{v})$, visualized with NP/PEG as follows: $5 \%(\mathrm{v} / \mathrm{v})$ ethanol NP (diphenylboric acid 2-aminoethyl ester, Sigma ${ }^{\circledR}$ ) followed by $5 \%(v / v)$ ethanol PEG 4000 (polyethylene glycol 4000), being visualized under UV light at $366 \mathrm{~nm}$ (Wagner \& Bladt, 1996). The alkaloid extract was prepared with $2 \mathrm{~g}$ of the $\mathrm{CE}$, shaken with
$10 \mathrm{~mL}$ of $0.05 \mathrm{M}$ sulphuric acid, then filtered. $1 \mathrm{~mL}$ of concentrated ammonia solution was added to this filtrate, which was then diluted to $10 \mathrm{~mL}$ with water, and extracted by shaking with $10 \mathrm{~mL}$ peroxide-free ether. The ether phase was evaporated to dryness and the subsequent residue was dissolved in methanol and tested through the following system: silica gel $\mathrm{G}$ $\left(\right.$ Merck $\left.^{\circledR}\right)$, chloroform:methanol:ammonium hydroxide $(80: 19: 1, \mathrm{v} / \mathrm{v})$, employing atropine sulfate $1 \%(\mathrm{~m} / \mathrm{v})$ as standard in a volume of $5 \mu \mathrm{L}$ and direct visualization, after splayed with Dragendorff reactive (Wagner \& Bladt, 1996).

\section{Flavonoid assay}

The flavonoid content of the drug powder was determined according to Motta et al. (2005). A total of $2 \mathrm{~g}$ of the drug powder was accurately weighed, brought to a boil in about $20 \mathrm{~mL}$ of methanol $80 \%$ and maintained at the boil for $10 \mathrm{~min}$. It was then cooled and filtered into a $50 \mathrm{~mL}$ volumetric flask. The drug was extracted twice and the solutions were cooled; they were then filtered and topped up to $50 \mathrm{~mL}$ with methanol $80 \%$. This solution was diluted 2500 -fold and $2 \mathrm{~mL}$ was transferred to a test tube, where $2 \mathrm{~mL}$ of aluminum chloride $5 \%(\mathrm{w} / \mathrm{v})$ and $6 \mathrm{~mL}$ of methanol $80 \%$ were added. Readings were taken from a Beckman Coulter DU-640 spectrophotometer at $420 \mathrm{~nm}$, after 30 min. A calibration curve was obtained using quercetin (Merck), with methanol $80 \%$ employed as a blank. The result, expressed as a percentage of the total flavonoid content, represents an average of three readings.

\section{Tannin assay}

The amount of total tannin in the C. racemosa drug powder was determined using the colorimetric methodology approved by the European Pharmacopoeia (1984). The test was performed in triplicate and the spectrophotometer readings were carried out at a wavelength of $715 \mathrm{~nm}$, after the addition of a recently prepared solution of phosphotungstic acid and topping up to $50 \mathrm{~mL}$ with a sodium carbonate $15 \%(\mathrm{~m} / \mathrm{v})$ solution. To calculate the amount of unabsorbed polyphenols, hide powder $\left(\mathrm{Merck}^{\circledR}\right)$ and pyrogallol standard $\left(\right.$ Merck $\left.^{\circledR}\right)$ were used.

compounds

Isolation of ethanolic fraction

An EF was used for the isolation of compounds and Column chromatography, paper chromatography and NMR (Nuclear Magnetic Resonance) were used to isolate the substances (Markham \& Geiger, 1996; Santos, 1998). A chromatographic glass column (60 
$\mathrm{cm} \times 3.5 \mathrm{~cm}$ of internal diameter) was filled with 35 $\mathrm{g}$ of Sigma ${ }^{\circledR}$ polyvinylpolypyrrolidone (PVPP) as a stationary phase and methanol was used as an eluant. Five grams of the EF was dissolved with a minimal amount of methanol, and this solution was introduced into the column. The fractions were gathered visually, directly from the column, accompanied by ultraviolet light $(366 \mathrm{~nm})$, and then successively concentrated in a Büchi ${ }^{\circledR}$ rotaevaporator. The concentrates were analyzed by TLC by using the chromatographic system: cellulose $\left(\right.$ Merck $\left.^{\circledR}\right)$, acetic acid $15 \%$ or $25 \%$ and UV $366 \mathrm{~nm}$, after detection with diphenylboryloxy-ethylamine (Wagner \& Bladt, 1996). Eighty fractions were obtained from the chromatographic column and, after selection by thin layer chromatographic profile likeness, sixteen fractions were regrouped. The regrouped fractions, 33-38 and 49-55, were subjected to descending paper chromatography. Whatman ${ }^{\circledR} 3 \mathrm{MM}$ paper was used to isolate the substances and then, when necessary, Whatman ${ }^{\circledR} 3$ to achieve final purification. The mobile phase employed was acetic acid at $15 \%$. The papers were evaluated under ultra violet light $(366 \mathrm{~nm})$ and the bands marked, cut and extracted under reflux, using methanol as a solvent. Each band was filtered and concentrated in a $\mathrm{Büchi}^{\circledR}$ rotaevaporator. When there was a sufficient quantity of the substance, a nuclear magnetic resonance (NMR) spectrum was obtained. From the 33-38 fraction, a characteristic purple compound was isolated under $366 \mathrm{~nm}$ ultraviolet light, which was then called $\mathrm{C} 1(9 \mathrm{mg})$, and from the $49-55$ fraction, a yellow compound was isolated under 366 $\mathrm{nm}$ ultraviolet light, and called C2 (12 mg). The C1 sample was analyzed with a Bruker ${ }^{\circledR}$ Advances DPX 300 spectrometer, at 300 megahertz (MHz), whilst the C2 sample was analyzed on a DPX 500 spectrometer, at $500 \mathrm{MHz}$. The samples were dissolved in deuterated dimethyl sulfoxide (DMSOd6) solvent.

\section{Biological assays}

\section{Antimicrobial activity of $\mathrm{CE}$}

The dilution in a liquid medium (Farmacopeia Brasileira, 1988) method was used. In this study, the microorganisms used for the assay were Staphylococcus aureus ATCC 6538, Pseudomonas aeruginosa ATCC 9027 and Escherichia coli ATCC 10536, Candida albicans ATCC 10231 and Aspergillus niger ATCC 16404. The bacterial strains were maintained in casein soy broth (Difco), whilst the yeasts and molds were maintained in Saboraud dextrose broth (Difco). The CE was dissolved in ethanol $70 \%$ at $0.5,1,1.5$ and $2 \mathrm{mg} / \mathrm{mL}$ concentrations. A secondary standard of chloramphenicol $(2.0,5.0$ and $8.0 \mu \mathrm{g} / \mathrm{mL})$, for bacteria, and amphotericin $\mathrm{B}(1,1.5,2,3$ and $4 \mu \mathrm{g} / \mathrm{mL})$, for yeast and mold, were used as positive inhibition controls (Silva, 2001). The tubes were incubated for $24 \mathrm{~h}$, or until development of the microorganisms in the control tubes, at a temperature of $30-35^{\circ} \mathrm{C}$, for bacteria, and $20-25{ }^{\circ} \mathrm{C}$ for mold. The assay was executed in triplicate. A subculture was made in the tubes that presented a precipitate but did not exhibit turbidity.

\section{franciscana) \\ Cytotoxicity assay (lethality of Artemia}

This assay was performed according to Suffredini (2000). Initially, the potential of the CE was ascertained by using a single $1 \mathrm{mg} / \mathrm{mL}$ dose. As there was a $50 \%$, or greater, mortality rate among the brine shrimp within 24 h, DL50 (Lethal Dose 50) was determined. The crustaceans (Artemia franciscana) were reared from dried eggs, which are viable for several years in this state. About $50 \mathrm{mg}$ of the eggs were placed into a rectangular opaque plastic container with artificial seawater, prepared from a mixture of commercial salt, according to the manufacturer's recommendations (São Francisco Bay Brand \# 65034). After 48 h, the brine shrimp that hatched were phototropically drawn to a cold light source. Ten brine shrimp were collected in a Pasteur pipette, and placed in $10 \mathrm{~mL}$ flasks, with 5 $\mathrm{mg}$ of the sample to be tested. The volume was topped up to $5 \mathrm{~mL}$ with seawater (concentration: $1 \mathrm{mg} / \mathrm{mL}$ ). Illumination was kept constant and the survivors were counted after 24 and $48 \mathrm{~h}$. For the assay to ascertain DL 50 , the $0.5 \mathrm{mg} / \mathrm{mL}, 0.1 \mathrm{mg} / \mathrm{mL}$ and $0.02 \mathrm{mg} / \mathrm{mL}$ concentrations of the $\mathrm{CE}$ were tested in triplicate, following the same procedure as before. DL50 was ascertained by counting the surviving brine shrimp after $24 \mathrm{~h}$, and the calculation was carried out using the Taxonomy software program. The EF, WEF and extracted fraction as per Wagner \& Bladt (1996) for the alkaloid compounds were also tested.

\section{Results and Discussion}

The genus Cuscuta is taxonomically controversial because it is classified as belonging to the Convolvulaceae family, but due to its parasitic properties, a number of schemata propose it to be a member of the monogeneric Cuscutaceae family (Cronquist, 1981; Dahlgren, 1981). Out of the approximately 180 species that compose the genus Cuscuta (Costea et al., 2008), many are difficult to identify or differentiate, because their inherent taxonomic properties are almost entirely related to their flowers, fruits and inflorescence, whereas their vegetative parts, characterized by their very simple structures, present great uniformity (Correa, 1984; Löffler et al., 1997).

The presence of flavonols derived from 
kaempferol and quercetin has been investigated in specimens of the Convolvulaceae family by many researchers, whilst flavonols like quercetin, kaempferol and hyperoside have been isolated in $C$. micrantha, $C$. reflexa, C. platyloba and C. chinensis (Garcia et al., 1995; Löffler et al., 1995; Yen et al., 2008). Bacchi (1993) indicated the presence of the flavonoid 3',4',5,7tetramethyl ether of quercetin in C. racemosa.

In this study, the thin-layer chromatographic profile (Figure 1) of the $\mathrm{CE}$ and the fractions obtained from the latter (WEF, EF, EAF and CF) indicates the presence of flavonoids, when revealed with diphenylboryloxy-etilamine (Wagner \& Bladt, 1996). And the assay ascertained that the drug powder consisted of $2.79 \%$ flavonoids and $2.01 \%$ tannins.

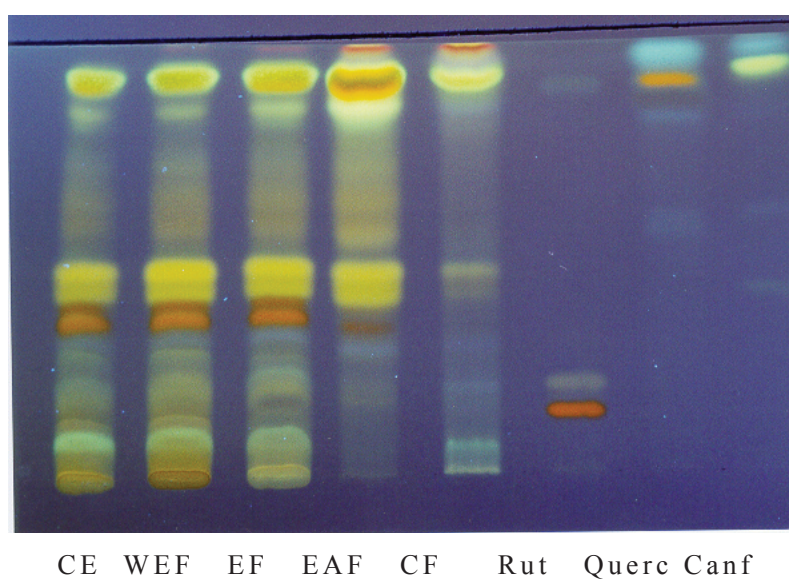

Figure 1. Chromatographic profile of extracts of C. racemosa. CE: lyophilized raw extract; WEF: ethanolic fraction $50 \%$; EF: ethanolic fraction; EAF:ethyl acetate fraction; CF chloroform fraction; Rut: rutin; Querc: quercetin; canf: kaempferol. Revealed with diphenylboryloxy-etilamine and UV light (Wagner \& Bladt, 1996).

The ethanolic fraction was subjected to the chromatographic column using adsorbent polyvinylpolypyrrolidone, and paper chromatography was employed to purify and isolate the compounds. Two substances ( $\mathbf{1}$ and $\mathbf{2}$ ) were isolated and analyzed by NMR.
From the data found in literature pertaining to studies of flavonoids in this genus, the proton $\left({ }^{1} \mathrm{H}\right)$ and carbon $\left({ }^{13} \mathrm{C}\right)$ spectra of 1 (Table 1) were compared with data from literature, which indicated hyperoside (Markham \& Geiger, 1996). For the compound 2, attributions of ${ }^{1} \mathrm{H}$ and ${ }^{13} \mathrm{C}$ NMR+HMBC spectroscopic data (Table 2), led to the conclusion that it was the 4'methoxyquercetin flavonoid.

In the antimicrobial assay, the CE presented activity with regards to the gram-positive bacteria Staphylococcus aureus, with a minimum inhibitory concentration of $2 \mathrm{mg} / \mathrm{mL}$. Doses of $0.5,1$ and 1.5 $\mathrm{mg} / \mathrm{mL}$ also indicated some activity, although when the subculture was made, there was growth, proving the viability of such microorganisms. This extract did not have any effect on Escherichia coli, Pseudomonas aeruginosa, Candida albicans and Aspergillus niger. Considering that phenolic compounds are recognized antimicrobial substances, the activity before the Staphylococcus aureus can be attributed to the presence of flavonoids and tannins. However, Rios et al. (1988) suggested a concentration of $100 \mu \mathrm{g} / \mathrm{mL}$ for plant extracts to present some antimicrobial potential and, accordingly, the value of $2 \mathrm{mg} / \mathrm{mL}$, found in this study, would not be a promising result.

The CE was effective with a single dose of $1 \mathrm{mg} /$ $\mathrm{mL}$ in the preliminary assay performed in the brine shrimp lethality test, causing the death of $50 \%$ of the crustaceans within $24 \mathrm{~h}$, and $100 \%$ within $48 \mathrm{~h}$, which is enough to characterize a positive result in terms of this activity (Suffredini, 2000) and to proceed with the test to ascertain DL50. The result of DL50 was found to be $231 \mu \mathrm{g} / \mathrm{mL}$. Significant values for this assay correspond to numbers lower than $1000 \mu \mathrm{g} / \mathrm{mL}$ (Suffredini, 2000). Therefore, the CE presented a significant result in this assay, although, when compared to the DL50 of the vincristine sulfate standard $(1.2 \mu \mathrm{g} / \mathrm{mL})$ obtained by Suffredini (2000), the $\mathrm{CE}$ value found presented a less active extract.

As a result of the values obtained, new tests were carried out, with EF, WEF and with an extract prepared as per Wagner \& Bladt (1996), for alkaloids. Upon analysis of the results after $24 \mathrm{~h}$, the EF and WEF did not show pertinent activity for continuity and determination of DL50. However, the alkaloid-directed extract ascertained<smiles></smiles>

1<smiles>COc1ccc(-c2oc3cc(O)cc(O)c3c(=O)c2O)cc1O</smiles> 
Table 1. ${ }^{1} \mathrm{H}$ and ${ }^{13} \mathrm{C}$ NMR spectroscopic data of compound $\mathbf{1}$ (DMSO-d6, $\delta$ ppm, $300 \mathrm{MHz}$ ).

\begin{tabular}{|c|c|c|c|c|}
\hline $\mathrm{N}^{\circ}$ & ${ }^{1} \mathrm{H}$ NMR* & Encountered & $\begin{array}{c}{ }^{13} \mathrm{C} \mathrm{NMR} \\
(\mathrm{ppm}) *\end{array}$ & Encountered \\
\hline 2 & - & - & 156.3 & 157.1 \\
\hline 3 & O- gal & O-gal & 133.8 & 134.3 \\
\hline 4 & - & - & 177.5 & 178.3 \\
\hline 5 & $12,61(\mathrm{OH})$ & $* * *$ & 161.2 & 162.1 \\
\hline 6 & $6,22 d$ & $6,20 \mathrm{~d}$ & 98.6 & 99.5 \\
\hline 7 & $\mathrm{OH}$ & $\mathrm{OH}$ & 164.0 & 164.9 \\
\hline 8 & $6,42 d$ & $6,41 d$ & 93.4 & 94.3 \\
\hline 9 & - & - & 156.3 & 157.1 \\
\hline 10 & - & - & 104.0 & 104.7 \\
\hline 1 ' & - & - & 121.3 & 121.9 \\
\hline $2^{\prime}$ & $7,55 \mathrm{~d}$ & 7,53 & 115.2 & 116.0 \\
\hline 3 & $\mathrm{OH}$ & $\mathrm{OH}$ & 144.7 & 145.7 \\
\hline $4^{\prime}$ & $\mathrm{OH}$ & $\mathrm{OH}$ & 148.5 & 149.3 \\
\hline 5, & $6,84 d$ & $6,83 \mathrm{~d}$ & 116.2 & 116.8 \\
\hline 6 & $7,68 \mathrm{dd}$ & $7,68 \mathrm{dd}$ & 121.8 & 122.8 \\
\hline $1 "$ & - & - & 102.3 & 102.6 \\
\hline $2 "$ & - & - & 71.3 & 72.0 \\
\hline $3 "$ & - & - & 73.4 & 74.0 \\
\hline $4 "$ & - & - & 68.0 & 68.7 \\
\hline $5 "$ & - & - & 75.8 & 76.7 \\
\hline $6 "$ & - & - & 60.8 & 60.95 \\
\hline
\end{tabular}

*For hyperoside (Markham \& Geiger, 1996). ** field not registered.

Table 2. ${ }^{1} \mathrm{H}$ and ${ }^{13} \mathrm{C}$ NMR+HMBC spectroscopic data of compound 2 (DMSO-d6, $\delta$ ppm, $500 \mathrm{MHz}$ ).

\begin{tabular}{|c|c|c|c|}
\hline \multirow[b]{2}{*}{$\mathrm{N}^{\circ}$} & \multicolumn{2}{|c|}{ Compound 2} & \multirow[b]{2}{*}{ Groups } \\
\hline & $\begin{array}{c}{ }^{1} \mathrm{H} \\
\mathrm{NMR}(\mathrm{ppm})\end{array}$ & $\begin{array}{c}{ }^{13} \mathrm{C} \mathrm{NMR+HMBC} \\
(\mathrm{ppm})\end{array}$ & \\
\hline 2 & & 150.6 & $-\mathrm{C}-$ \\
\hline 3 & 9.51 & 139.8 & $-\mathrm{C}-\mathrm{OH}$ \\
\hline 4 & & 179.9 & $\mathrm{C}=\mathrm{O}$ \\
\hline 5 & 12.55 & 164.7 & $-\mathrm{C}-\mathrm{OH}$ \\
\hline 6 & 6.29 & 102.2 & $-\mathrm{CH}$ \\
\hline 7 & 10.89 & 167.9 & $-\mathrm{C}-\mathrm{OH}$ \\
\hline 8 & 6.58 & 97.6 & $-\mathrm{CH}$ \\
\hline 9 & - & 160.1 & $-\mathrm{C}-$ \\
\hline 10 & - & 107.0 & $-\mathrm{C}-$ \\
\hline $1^{\prime}$ & - & 125.7 & $-\mathrm{C}-$ \\
\hline 2 ' & 7.79 & 115.7 & $-\mathrm{CH}$ \\
\hline $3^{\prime}$ & 9.84 & 152.8 & $-\mathrm{C}-\mathrm{OH}$ \\
\hline $4^{\prime}$ & 3.94 & 151.4 & $-\mathrm{C}-\mathrm{OH}$ \\
\hline 5 & 7.03 & 119.5 & $-\mathrm{CH}$ \\
\hline $6^{\prime}$ & 7.85 & 126.0 & $-\mathrm{CH}$ \\
\hline 4'-OMe & - & 59.8 & $-\mathrm{OCH}_{3}$ \\
\hline
\end{tabular}

by TLC (Wagner \& Bladt, 1996) proved to be effective in the assay, by eliminating all the brine shrimp within $24 \mathrm{~h}$.

Mavlonov et al. (2008) evaluated cytotoxic activity in three species of Cuscuta (C. europea, C. lupuliformis and $C$. attenuate) in a model of murine cancer and ascertained elevated cytotoxic activity of a component of a polar fraction (aqueous extract) of C. europea.

For some specimens of the genus Cuscuta, alkaloids with indolic nuclei were discovered, which are considered to be potential antitumor substances (Nisa et al., 1986). Hofmann \& Tscherter (Chao \& Der Marderosian, 1973) were the first researchers to isolate ergoline-type alkaloids (indolic nuclei) in superior plants, since before the 1960s, this kind of alkaloid had only been found in the fungi of the genus Claviceps. Since the Aztec times (Mexico), the seeds of Rivea corymbosa and Ipomoea violacea (specimens of the Convolvulaceae family) have been used in religious ceremonies for hallucinogenic purposes. A wide range of ergoline-type alkaloids has been confirmed in plants of the genus Argyreia, as well as in others of the Convolvulaceae family, like Rivea, Stictocardia and also Cuscuta (C. monogyna and C. chinensis).

Pérez-Amador et al. (1996), working with four species of the genus Cuscuta, after determining the chromatographic profiles of ergolinic alkaloids, glycoresins and kaurenoic glycosides (diterpenoids), which had been suggested as taxonomic markers of the Convolvulaceae family, considered them part of the Convolvulaceae family, rather than a classification apart, as suggested by Cronquist (1981) and Dahlgren (1981).

\section{Conclusion}

In addition to other species of the genus Cuscuta, the C. racemosa Mart. presented flavonoid compounds $(2.79 \%)$ as the main metabolite. The presence of flavonol, reported by several authors, was also revealed in this study (4'methoxyquercetin). Despite flavonoids being known for several biological activities, the lyophilized raw extract of the drug in question presented modest and marginally positive antimicrobial activity for the microorganism Staphylococcus aureus. In the lethality assay involving Artemia franciscana, the extract, in the form of a single $1 \mathrm{mg} / \mathrm{mL}$ dose, was able to eliminate $50 \%$ of the brine shrimp within $24 \mathrm{~h}$ and $100 \%$ within $48 \mathrm{~h}$, resulting in a DL50 of $231 \mu \mathrm{g} / \mathrm{mL}$. Although some flavonoids are known for their cytotoxic activity, the ethanolic and 50\% ethanolic extracts did not prove to be effective; however, the alkaloid-directed extract was able to eliminate $100 \%$ of the brine shrimp within the 24-h period, indicating very significant activity. The cytotoxicity results obtained here, associated with the presence of alkaloids, suggested as a phytochemical marker of the Convolvulaceae family, and found in the species of the genus Cuscuta, indicate that this 
phytochemical group is worthy of future studies involving the species $C$. racemosa.

\section{Acknowledgements}

Rosângela Bianchini, $\mathrm{PhD}$, expert in Convolvulaceae, at the Herbarium of the Botany Institute of São Paulo.

\section{References}

Alves NB, Seki FR, Bacchi EM 1995. Ação antiúlcera de Cuscuta racemosa Martius. Reunião de iniciação científica na $F C F / U S P$. São Paulo, Brazil.

Bacchi EM 1993. Flavonoids from Cuscuta racemosa. Annual congress on medicinal plant research. Düsseldorf, Germany.

Bungard RA 2004. Photosynthetic evolution in parasitic plants: insight from the chloroplast genome. Bioessays 26: 235 247.

Chao JM, Der Marderosian HA 1973. Identification of ergoline alkaloids in the genus Argyreia and related genera and their chemotaxonomic implications in the Convolvulaceae. Phytochemistry 12: 2435-2440.

Correa MP 1984. Dicionário das plantas úteis do Brasil e das exóticas cultivadas. Rio de Janeiro: Ministry of Agriculture.

Costea M, Aiston F, Stefanovic S 2008. Species delimitation, phylogenetic relationships, and two new species in the Cuscuta gracillima complex (Convolvulaceae). Botany 86: 670-681.

Cronquist A 1981. An integrated system of classification of flowering plants. New York: Columbia University.

Dahlgren RMT 1981. A revised classification of the Angiosperms with comments on correlation between chemical and other characters. In: Young DA, Seigler DS (orgs.) Phytochemistry and angiosperm phylogeny. New York: Praeger Publishers, p.149-204.

European Pharmacopoeia 1984. Strasbourg: Council of Europe, 2 ed.

Farmacopeia Brasileira 1988. São Paulo: Atheneu, 4a ed.

Garcia R, Erazo MS, Pena RC 1995. Flavonoids and alkaloids from Cuscuta (Cuscutaceae). Biochem Syst Ecol 23: 571572.

Löffler C, Czygan FC, Proksch P 1997. Phenolic constituents as taxonomic markers in the genus Cuscuta (Cuscutaceae). Biochem Syst Ecol 25: 297-303.

Löffler C, Sahm A, Wray V, Czygan FC, Proksch P 1995. Soluble phenolic constituents from Cuscuta reflexa and Cuscuta platyloba. Biochem Syst Ecol 23: 121-128.

Lorenzi H 2000. Plantas daninhas do Brasil. Nova Odessa: Instituto Plantarum.

Markham KR, Geiger H 1996. 'H nuclear magnétic resonance spectroscopy of flavonoids and their glycosides in hexadeuterodimethylsulfoxide. In: Harborne JB (org.) The flavonoids. London: Chapman \& Hall, p.441-498.

Mavlonov GT, Ubaidullaeva KA, Kadryaeva GV, Kuznetsova NN 2008. Cytotoxic components of Cuscuta. Chem Nat Compd 44: 409-410.

Motta LB, Kraus JE, Salatino A, Salatino MLF 2005. Distribution of metabolites in galled and non-galled foliar tissues of Tibouchina pulchra. Biochem Syst Ecol 33: 971-981.

Nisa M, Akbar S, Tariq M, Hussain Z 1986. Effect of Cuscuta chinensis water extract on 7,12-dimethylbenz $[\alpha]$ anthracene-induced skin papillomas and carcinomas in mice. J Ethnopharmacol 18: 21-31.

Pèrez-Amador MC, Arreola L, Márquez-Guzman J, GarciaArgáez A 1996. Seasonal influence on the biosynthesis of ergoline alkaloids in the genus Cuscuta (Convolvulaceae). Phyton 59: 51-54.

Press MC, Phoenix GK 2005. Impacts of parasitic plants on natural communities. New Phytol 166: 737-751.

Rios JL, Recio MC, Villar A 1988. Screening methods for natural products with antimicrobial activity: a review of the literature. J Ethnopharmacol 23: 1127-1149.

Santos DYAC 1998. Implicações taxonômicas dos flavonóides de Annonaceae. São Paulo, 107 p. PhD Dissertation, Biosciences Institute of the University of São Paulo.

Shen H, Ye W, Hong L, Huang H, Wang Z, Deng X, Yang Q, Xuet Z 2006. Progress in parasitic plant biology: host selection and nutrient transfer. Plant Biol 8: 175-185.

Silva MG 2001. Estudo farmacognóstico de Myrciaria glomerata Berg. São Paulo, 149 p. Master Degree Dissertation, Pharmaceutical Sciences College of the University of São Paulo.

Suffredini IB, Bacchi EM, Sertiè JAA 1999. Antiulcer action of Microgramma squamulosa (Kaulf) Sota. $J$ Ethnopharmacol 65: 217-223.

Suffredini IB 2000. Avaliação da atividade citotóxica, antiviral $e$ antimicrobiana de Apocynaceae amazônicas. São Paulo, 220 p. PhD Dissertation, Pharmaceutical Sciences College of the University of São Paulo.

Wagner H, Bladt S 1996. Plant drug analysis. Berlim: SpringerVerlag.

Yen FL, Wu TH, Lin LT, Cham TM, Lin CC 2008. Concordance between antioxidant activities and flavonol contentsin different extracts and fractions of Cuscuta chinensis Food Chem 108: 455-462.

\section{*Correspondence}

Helena O. Ferraz

Universidade de Sorocaba, Rodovia Raposo Tavares km 92.5, 18023-000 Sorocaba-SP, Brazil

helena.ferraz@prof.uniso.br

Tel. +551521017079 